\title{
Effect of Boron Soil Application on Nutrients Efficiency in Tobacco Leaf
}

\author{
Fayaz Ali', Amjad Ali1 ${ }^{*}$, Hameed Gul2, Muhammad Sharif ${ }^{3}$, Arooj Sadiq4 ${ }^{4}$ Ansaar Ahmed5, \\ Arif Ullah', Amanullah Mahar', Shahmir Ali Kalhoro7 \\ ${ }^{1}$ College of Natural Resources and Environment, Northwest A \& F University, Yangling, China \\ ${ }^{2}$ Pakistan Tobacco Board, Tobacco Research Station, Mardan, Pakistan \\ ${ }^{3}$ Department of Soil and Environmental Sciences, University of Agriculture, Peshawar, Pakistan \\ ${ }^{4}$ Department of Agriculture Resource and Environmental Sciences, Northeast Agriculture University, Harbin, China \\ ${ }^{5}$ Department of Agronomy, University of Agriculture, Peshawar, Pakistan \\ ${ }^{6}$ College of Economics and Management, Northwest A \& F University, Yangling, China \\ ${ }^{7}$ Faculty of Agriculture, Lasbela University of Agriculture, Water \& Marine Sciences, Lasbela, Pakistan \\ Email: amjadali@aup.edu.pk
}

Received 30 March 2015; accepted 12 June 2015; published 15 June 2015

Copyright (C) 2015 by authors and Scientific Research Publishing Inc.

This work is licensed under the Creative Commons Attribution International License (CC BY).

http://creativecommons.org/licenses/by/4.0/

c) (i) Open Access

\begin{abstract}
The present study was based on the general hypothesis that boron may affect the accumulation and utilization of other nutrients in plant. For this purpose a field experiment was carried out to find out the influence of boron on the different nutrients content in FCV tobacco (Nicotiana tabacum L.) at TRS Khan Garhi, Mardan, during 2010-2011. Two varieties TM-2008 and Speight G-28 were tested and six levels of boron $\left(0,0.5,1,2,3\right.$ and $\left.5 \mathrm{~kg}^{-h a^{-1}}\right)$ were applied in the form of boric acid, in randomized complete block design in split plot arrangement and replicated thrice. Results indicated that the yield of tobacco crop increased with $1 \mathrm{~kg} \cdot \mathrm{B} \cdot \mathrm{ha}^{-1}$ and then decreased sequence wise in both varieties. $N$ and $P$ concentrations were significantly affected by applied boron. Similarly, potassium was increased which is a good indication for a better quality of tobacco crop. Application of boron significantly increased the concentrations of boron nutrients ratios such as K/B; $\mathrm{Cl} / \mathrm{B}$ and $\mathrm{Mn} / \mathrm{Fe}$ were decreased while $\mathrm{K} / \mathrm{Cl}$ and $\mathrm{Zn} / \mathrm{Cu}$ ratios were increased at lower boron concentrations but decreased at higher concentrations of boron. The fertilizer use efficiency of both the cultivars showed similar trend; however, Speight G-28 was more efficient than TM-2008 in boron accumulation. The overall results revealed that the application of boron should be encouraged for balancing nutrients concentration, thus getting higher yield in the prevailing conditions.
\end{abstract}

\section{Keywords}

Boron, Nutrients Efficiency, Nitrogen, Phosphurus, Tobacco

\footnotetext{
"Corresponding author.
}

How to cite this paper: Ali, F., Ali, A., Gul, H., Sharif, M., Sadiq, A., Ahmed, A., Ullah, A., Mahar, A. and Kalhoro, S.A. (2015) Effect of Boron Soil Application on Nutrients Efficiency in Tobacco Leaf. American Journal of Plant Sciences, 6, $1391-1400$. 


\section{Introduction}

Boron (B) is required for all plant growth. Adequate B nutrition is critical for high yields and quality of crops. Deficiencies of B result in many anatomical, biochemical and physiological changes in plants. It is a widespread agricultural problem in the world, which results in yield and quality loss of many crop species including tobacco [1]-[5]. B deficiency affects vegetative and reproductive growth of plants, resulting in inhibition of cell expansion and death of meristem cells [6], and affects the utilization of other plant nutrients [7]. Boron cannot be redistributed rapidly within most species of plants; even a small interruption of nutrient supply from the soil may depress the growth and yield loss can occur. The amount of yield losses directly depends upon the duration of deficiency and the plant growth stage at which it occurs [8]. Mahler [9] found that the role of boron is in the transmission of sugar across the membranes, differentiation and development of cell and also in auxin metabolism. It has been known that an optimal boron level for one crop species could be either toxic or inadequate for other crop species [10]. It is well defined that the chemistry of boron in soil and its role in plants are different from other elements, but its deficiency or toxicity can affect the solubility and availability of elements in soil [11] [12] and total uptake in plants body [13]-[16].

Tobacco (Nicotiana tabacum L.) belongs to the family Solanaccae, which is grown all over the world for the manufacturing of cigarettes, cigars and bids; in addition tobacco is used for hoqqa, snuffs and chewing [17]. Farmers obtain higher net return from tobacco as compared to other cash crops. In Pakistan, especially in Khyber Pakhtunkhwa, tobacco is the major cash crop for the farmers. The chemical composition of tobacco leaf plays a key role in the evaluation of tobacco quality. The absolute and relative amount of these constituents not only depends on crop varieties and maturity, soil, climatic condition and curing process, but also depends on the responsive mineral nutrition of tobacco crop, such as boron [18] [19]. Boron is one of the major deficient micronutrients after zinc in Pakistan [20], and B not only affects the yield but also affects the marketing value of tobacco leaf. It is apparent from the previous literature that boron may affect other micronutrients in soil and also in the plants. However, literary information on the subject of the effect of boron on the concentration, uptake and transportation of plant nutrients is insufficient. The changes in mineral nutrients composition induced by boron were observed by various researchers in different crops such as maize [21], sunflower [14], wheat [22] and radish [15], and this could be demonstrated in different cultivars of tobacco. For this purpose an experiment was carried out to test a general hypothesis that boron may affect the accumulation and utilization of other nutrients in plants and also to find out the suitable level of boron for getting higher yield and better quality of tobacco crop.

\section{Materials and Methods}

\subsection{Experimental Layout and Sampling}

A field experiment was conducted to study the influence of boron on the nutrients content of FCV tobacco ( $\mathrm{Ni}$ cotiana tabacum L.) in PTB, Tobacco Research Station, Khan Garrhi Mardan-Pakistan, during 2010-2011. The varieties TM-2008 and Speight-G 28 were grown. The experiment was laid out in randomized complete block design in split plot arrangement, where main plots consisted of 2 varieties and sub plots consisted of 6 levels of boron and replicated thrice. Seeds of tobacco were sown in the $1^{\text {st }}$ week of December, 2010 and then in the $2^{\text {nd }}$ week of March, 2011, healthy seedling was transplanted to the treated plots. The plot size was $6 \times 2.7 \mathrm{~m}^{2}$, with $90 \mathrm{~cm}$ row to row distance and $60 \mathrm{~cm}$ plant to plant distance. The boron was applied at varying rates of 0 , $0.5,1,2.0,3.0$ and $5.0 \mathrm{~kg} \cdot \mathrm{ha}^{-1}$ in the form of boric acid. A basal dose of $\mathrm{N}, \mathrm{P}_{2} \mathrm{O}_{5}$ and $\mathrm{K}_{2} \mathrm{O}$ at the rate of 70 $\mathrm{kg} \cdot \mathrm{ha}^{-1}$ each was applied in the form of compound fertilizer with 15:15:15. All fertilizers were applied at the time of transplantation. The tobacco plants were topped at 22nd leaf stage. A composite soil sample from $20 \mathrm{~cm}$ depth was collected before the conductance of experiment and analyzed for various physico-chemical properties of the soil by standard routine methods. Collection of representative leaf samples from each treatment plot was done after curing and then analyzed for the required qualitative and quantitative parameters. All the recommended and routine agronomic practices were carried out during growing season.

\subsection{Plant Analysis}

Representatives plant cured leaf samples were dried, ground by using Willy mill and ashed in a muffle furnace [23]. Boron concentration in the digest was determined by spectrophotometer using Azomathine-H method [24], 
while $\mathrm{K}$ by using flame photo meter and $\mathrm{Zn}, \mathrm{Cu}, \mathrm{Fe}$, and $\mathrm{Mn}$ by atomic absorption spectrophotometer. Nitrogen was determined by [25].

\subsection{Statistical Analysis}

The collected data during the investigations of field and laboratory analysis was analyzed statistically, using ANOVA technique and the means comparison was done by LSD test of significance [26].

\section{Results and Discussion}

The physico-chemical properties of soil are presented in Table 1 . The test soil was almost neutral in reaction, silt loam in texture, slightly calcareous, non-saline, low in organic matter, deficient in AB-DTPA extractable K, $\mathrm{Fe}, \mathrm{Zn}$ and adequate in soluble $\mathrm{Cl}, \mathrm{Cu}, \mathrm{Mn}$ and dilute $\mathrm{HCl}$ extractable boron [27] [28].

\subsection{Nitrogen}

That data showed that applied boron significantly $(P<0.05)$ affected the nitrogen concentration in tobacco leaves (Table 2). The data showed that as the applied boron increased, the $\mathrm{N}$ concentration also increased but

Table 1. Physico-chemical properties of the test soil.

\begin{tabular}{ccc}
\hline Parameter & Units & Values \\
Sand & $\%$ & 21.13 \\
Silt & $\%$ & 66.45 \\
Clay & $\%$ & 12.42 \\
Textural class & - & Silt loam \\
Lime (CaCO $)_{3}$ & $\%$ & 11.5 \\
Organic matter & $\%$ & 0.40 \\
pH (1:5) & - & 7.20 \\
EC (1:5) & $\mathrm{dS} \cdot \mathrm{m}^{-1}$ & 0.15 \\
Total N & $\%$ & 0.08 \\
AB-DTPA extractable P & $\mathrm{mg} \cdot \mathrm{kg}^{-1}$ & 5.75 \\
AB-DTPA extractable K & $\mathrm{mg} \cdot \mathrm{kg}^{-1}$ & 74 \\
Soluble Cl & $\mathrm{mg} \cdot \mathrm{kg}^{-1}$ & 28 \\
AB-DTPA-extractable Cu & $\mathrm{mg} \cdot \mathrm{kg}^{-1}$ & 1.74 \\
AB-DTPA-extractable $\mathrm{Zn}$ & $\mathrm{mg} \cdot \mathrm{kg}^{-1}$ & 0.51 \\
AB-DTPA-extractable Fe & $\mathrm{mg} \cdot \mathrm{kg}^{-1}$ & 0.97 \\
AB-DTPA-extractable Mn & $\mathrm{mg} \cdot \mathrm{kg}^{-1}$ & 11.17 \\
Dilute HCl extractable B & $\mathrm{mg} \cdot \mathrm{kg}^{-1}$ & 0.65 \\
\hline
\end{tabular}

Table 2. Boron effect on nitrogen concentration.

\begin{tabular}{|c|c|c|c|c|c|c|c|}
\hline \multirow{2}{*}{ Varieties } & \multicolumn{6}{|c|}{ B applied $\left(\mathrm{kg} \cdot \mathrm{ha}^{-1}\right)$} & \multirow{2}{*}{ Mean } \\
\hline & 0 & 0.5 & 1 & 2 & 3 & 5 & \\
\hline TM-2008 & 1.09ef & 1.14de & 1.12de & 1.15de & $1.20 \mathrm{bcd}$ & $1.18 \mathrm{~cd}$ & 1.15 \\
\hline Speight G-28 & 1.17cde & $1.28 \mathrm{~b}$ & $1.24 \mathrm{bc}$ & $1.37 \mathrm{a}$ & $1.01 \mathrm{f}$ & 1.15de & 1.21 \\
\hline Mean & 1.13cd & $1.21 \mathrm{ab}$ & $1.18 b c$ & $1.26 a$ & $1.11 d$ & 1.17bcd & \\
\hline
\end{tabular}

LSD value $(P<0.05)$ for Boron $=0.066$; LSD value $(P<0.05)$ for boron $\times$ varieties $=0.094$; Means with different alphabets differ significantly. 
goes downward at higher levels. The data ranged from $1.01 \%-1.37 \% \mathrm{~N}$ in the leaves. Highest concentration of $1.37 \% \mathrm{~N}$ was observed for applied boron @ $2 \mathrm{~kg} \cdot \mathrm{ha}^{-1}$ in variety Speight G-28, while the lowest were 1.01 (for 3 $\mathrm{kg} \cdot \mathrm{B} \cdot \mathrm{ha}^{-1}$ in var. Speight G-28) and 1.09 (for TM-2008 at no boron level). Among the varieties, Speight G-28 accumulated more $\mathrm{N}$ as compared to TM-2008.

The relationship between $\mathrm{N}$ and $\mathrm{B}$ in this experiment clearly indicated that B can increase $\mathrm{N}$ content in tobacco leaves but higher levels of B can negatively affect it. Same results were observed in leaves of cotton [29]. Another study revealed that boron negatively affected different compounds of $\mathrm{N}$ [30], like decreased $\mathrm{NO}_{3}^{-}$ content, which is harmful for tobacco quality and health of smoker and on the other hand increased different $\mathrm{N}$ based enzymes which are beneficial for tobacco. Same trends were reported by [31] in rice and [32] in sugar beet grown in calcareous soil.

\subsection{Phosphorus}

The data for phosphorus content showed that B significantly affected P content in tobacco leaves (Table 3). The data ranged from $0.391 \%$ to $0.146 \%$ P. The highest (0.391\%) was observed for Speight G-28 @ $3 \mathrm{~kg} \cdot \mathrm{B} \cdot \mathrm{ha}^{-1}$, and the lowest was $0.146 \%$ recorded @ $0.5 \mathrm{~kg} \cdot \mathrm{B} \cdot \mathrm{ha}^{-1}$, followed by $0.152 \%$ recorded at no boron level, for Speight G-28 and TM-2008, respectively. Furthermore, the level of $3 \mathrm{~kg} \cdot \mathrm{ha}^{-1} \mathrm{~B}$ was accumulated the highest $\mathrm{P}$ content in the tobacco leaves. As the applied B increased, the P content also increased but decreased with high level of 5 $\mathrm{kg} \cdot \mathrm{B} \cdot \mathrm{ha}^{-1}$. Speight G-28 proved better in accumulating $\mathrm{P}$ in the case of $\mathrm{P}$ accumulation.

The data revealed that $\mathrm{B}$ has a positive effect on $\mathrm{P}$ concentration in tobacco leaves. This relationship was also found in cotton [29] and sugar beet [32]. In rice, although it was not very significant but showed an increasing trend [31]. Higher B concentration can affect the P concentration as reported by [33].

\subsection{Potassium}

The results regarding the potassium content showed non-significant differences among the tobacco treated plots and varietal response (Table 4). The data ranged from 1.01\% - 1.38\% in TM-2008 and $0.83 \%-1.12 \%$ in Speight G-28. Maximum potassium concentration was observed in the treatment plots where high boron levels were applied and minimum concentration was recorded in control plots in both varieties. However, results showed increasing trends with increase in applied boron which indicated that boron has a positive effect on potassium concentration in tobacco leaf. This positive effect of boron on potassium in tobacco is a good indicator for good quality tobacco, because potassium enhances the smoking and ashing quality by increasing the burning quality of tobacco. These findings are in conformation with the early work of [19] [34].

Table 3. Boron effect on phosphorus concentration.

\begin{tabular}{|c|c|c|c|c|c|c|c|}
\hline \multirow{2}{*}{ Varieties } & \multicolumn{6}{|c|}{ B applied $\left(\mathrm{kg} \cdot \mathrm{ha}^{-1}\right)$} & \multirow{2}{*}{ Mean } \\
\hline & 0 & 0.5 & 1 & 2 & 3 & 5 & \\
\hline TM-2008 & $0.152 \mathrm{f}$ & $0.362 \mathrm{ab}$ & $0.204 \mathrm{e}$ & $0.254 \mathrm{~cd}$ & $0.324 b$ & 0.214 de & 0.252 \\
\hline Speight G-28 & $0.250 \mathrm{~cd}$ & $0.146 \mathrm{f}$ & $0.270 \mathrm{c}$ & $0.198 \mathrm{e}$ & $0.391 \mathrm{a}$ & 0.227 cde & 0.247 \\
\hline Mean & $0.201 \mathrm{~d}$ & $0.254 \mathrm{~b}$ & $0.238 \mathrm{bc}$ & $0.226 \mathrm{bcd}$ & $0.358 \mathrm{a}$ & $0.220 \mathrm{~cd}$ & \\
\hline
\end{tabular}

LSD value $(P<0.05)$ for Boron $=0.0320$; LSD value $(P<0.05)$ for boron $\times$ varieties $=0.0453$; Means with different alphabets differ significantly.

Table 4. Effect of applied boron on the potassium content of tobacco (\%).

\begin{tabular}{|c|c|c|c|c|c|c|c|}
\hline \multirow{2}{*}{ Varieties } & \multicolumn{6}{|c|}{ B applied $\left(\mathrm{kg} \cdot \mathrm{ha}^{-1}\right)$} & \multirow{2}{*}{ Mean } \\
\hline & 0 & 0.5 & 1 & 2 & 3 & 5 & \\
\hline TM-2008 & 1.01 & 1.01 & 1.05 & 1.05 & 1.38 & 1.12 & 1.10 \\
\hline Speight G-28 & 0.83 & 0.94 & 1.11 & 1.07 & 1.11 & 1.12 & 1.03 \\
\hline Mean & 0.92 & 0.98 & 1.08 & 1.06 & 1.25 & 1.12 & \\
\hline
\end{tabular}




\subsection{Nutrient Ratios in Tobacco Leaf}

\subsubsection{K/B Ratio}

Results revealed that K/B ratio was linearly and significantly decreased in the tobacco leaves with increasing concentration of boron (Figure 1). This decrease is because of the significant increase in boron concentration and non-significant increase in potassium concentration of the leaves. These results are similar to the findings of Tariq et al. [19], who stated that as the boron concentration in tobacco leaf increases the K/B ratio considerably decreases. Similarly, decreasing trend for K/B ratio in other crops due to boron was also reported for cauliflower [35], radish [15] and tomato [36]. Moreover, results showed similar trends in both varieties of tobacco. Though the varietal differences in terms of $\mathrm{K} / \mathrm{B}$ ratio is statistically non-significant.

\subsection{2. $\mathrm{Cl} / \mathrm{B}$ Ratio}

It is clear from the results that as the boron concentration increases, the $\mathrm{Cl} / \mathrm{B}$ ratio significantly decreases, which results a negative relationship in both tobacco varieties (Figure 2). This decreasing trend may be due to the competition of these two anions on the uptake sites. The decreasing trend in $\mathrm{Cl} / \mathrm{B}$ ratio is a good indicator for tobacco because the $\mathrm{Cl}$ decreases the burning quality of tobacco and also affects the grade index. Similar results were observed for tobacco [19], hot pepper [37] and tomato crops [38].

\subsubsection{K/Cl Ratio}

The results showed that $\mathrm{K} / \mathrm{Cl}$ ratio in tobacco leaves increases with increasing concentration of boron in tobacco (Figure 3). This decrease with increasing concentration of boron was due to the increase in $\mathrm{K}$ and decrease in $\mathrm{Cl}$ in the tobacco leaf. The same trend in both varieties was observed showing no concern with $\mathrm{K} / \mathrm{Cl}$ ratio which confirms that boron is responsible for the changes in $\mathrm{K} / \mathrm{Cl}$ ratio of tobacco. However, the increase in $\mathrm{K} / \mathrm{Cl}$ ratio is a better sign for good quality of tobacco crop as stated earlier that $\mathrm{K}$ is needed for a better tobacco crop and lower concentration of $\mathrm{Cl}$. The results of the present study are supported by the work of Hashmi et al. [39], who
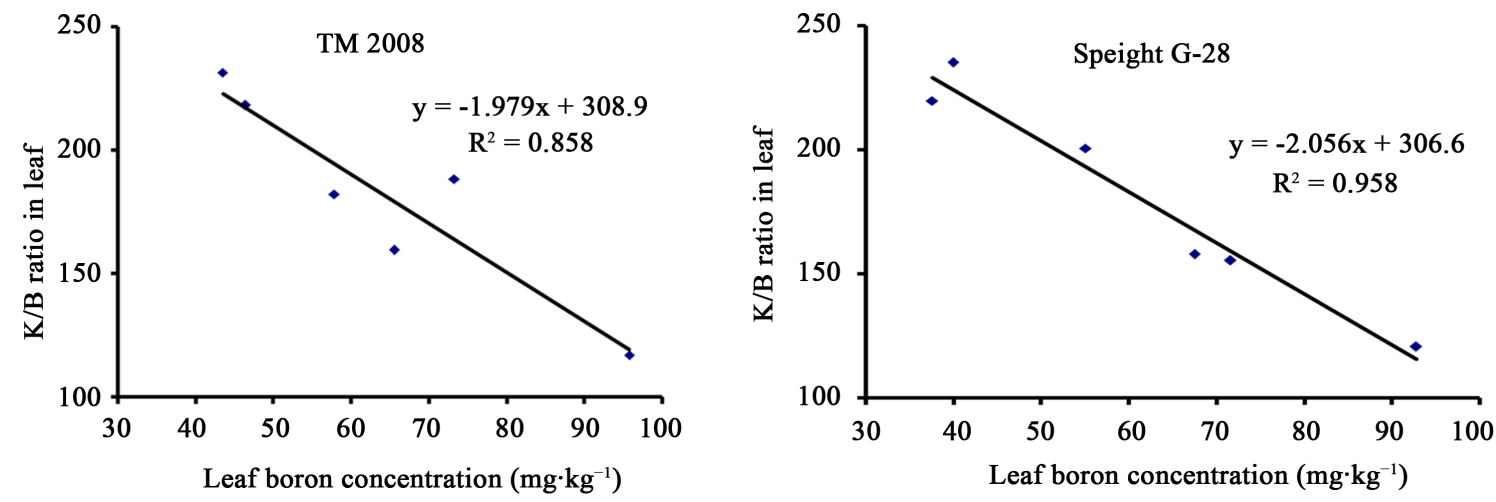

Figure 1. Relationship between boron concentration and K/B ratio of tobacco.
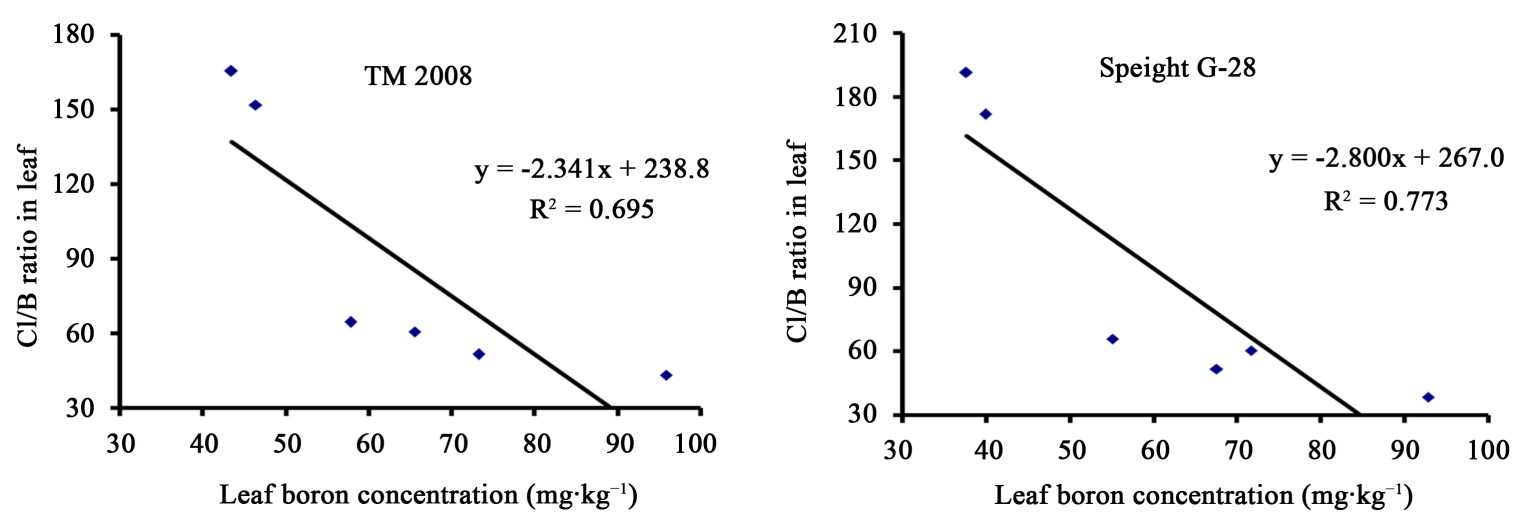

Figure 2. Relationship between boron concentration and Cl/B ratio of tobacco. 

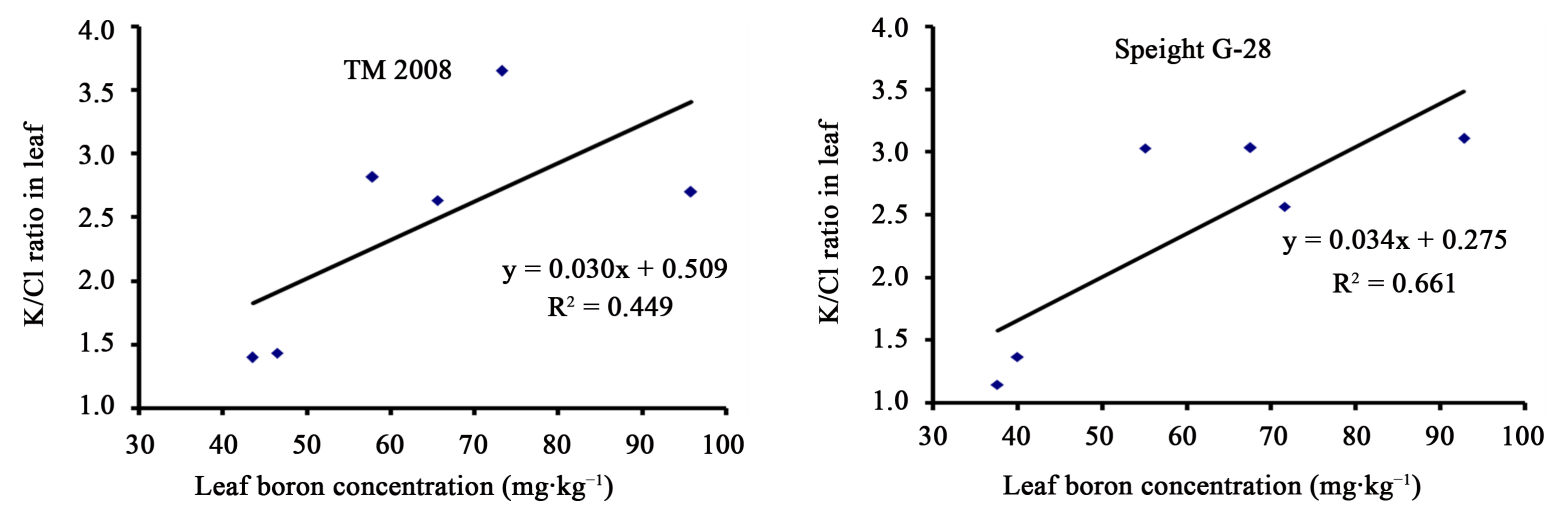

Figure 3. Relationship between boron concentration and $\mathrm{K} / \mathrm{Cl}$ ratio of tobacco.

stated that increase in $\mathrm{K}$ content of tobacco leaves decreases the $\mathrm{Cl}$ content, which indicated that $\mathrm{K}$ is responsible for lowering the $\mathrm{Cl}$ content of tobacco leaves.

\subsubsection{Zn/Cu Ratio}

It is evident from the results that $\mathrm{Zn} / \mathrm{Cu}$ ratio increases with increase in leaf boron concentration of tobacco (Figure 4). These results showed a close relationship of leaf boron with $\mathrm{Zn} / \mathrm{Cu}$ ratio in tobacco and the same trend was occurred in both varieties. These results are supported by the early work of Leece [33], who reported that higher boron levels increased the $\mathrm{Zn} / \mathrm{Cu}$ ratio in maize plant. Moreover, these findings are confirmed by Tariq and Mott [15], who stated that with increase in the concentration of boron in radish plant is proportional to increase in $\mathrm{Zn} / \mathrm{Cu}$ ratio occurs.

\subsubsection{Mn/Fe Ratio}

It is evident from the results that $\mathrm{Mn} / \mathrm{Fe}$ ratio decreases with increase in boron concentration of tobacco (Figure 5). These results indicated that Fe was increased and Mn was decreased with increase in boron content in leaf. Similar results were reported by Alvarez-Tinaut et al. [40], and Tariq and Mott [15]. They reported that $\mathrm{Mn} / \mathrm{Fe}$ ratio in the plant decreases with increase in boron concentration. These results also suggested that antagonism of $\mathrm{B}-\mathrm{Mn}$ can occur due to decrease in $\mathrm{Mn} / \mathrm{Fe}$ ratio in plant.

\subsection{Fertilizer Use Efficiency}

Fertilizer use efficiency for the boron in the present study calculated according to the procedure developed by Crawswell [41] to calculate the most efficient level of boron fertilizer (Figure 6). Results clearly revealed that applied B@ $1 \mathrm{~kg} \cdot \mathrm{ha}^{-1}$ accumulated maximum boron, gave greater yield, and produced good quality tobacco as compared to other levels of boron fertilizers applied. Perhaps, loss of boron due to leaching, precipitation, erosion, and adsorption in soil were minimized. So it may be concluded that application of boron @ $1 \mathrm{~kg} \cdot \mathrm{ha}^{-1}$ is more effective, economical and viable than other levels of boron fertilizer applied. Furthermore, we agreed with the findings of Roberts [42] who stated that efficiency of the fertilizer can be optimized through best fertilizer management practices, which supplies nutrients at the right time, rate, and place. Therefore, the fertilizer use efficiency of $1 \mathrm{~kg} \cdot \mathrm{B} \cdot \mathrm{ha}^{-1}$ proved better than other levels of applied boron and should be applied before the deficiency occurs, because tobacco crop become unable to recover from the physiological or morphological changes which results from low-boron status of soil.

\section{Conclusion}

This study concluded that boron can affect the nutrient balance in tobacco. Furthermore, it can increase the yield and enhance the quality of the crop. B can increase $\mathrm{N}$ content in tobacco leaves but higher levels of B can negatively affect it. B increases different N-based enzymes which are beneficial for tobacco, and on the other hand it can affect different compounds of $\mathrm{N}$, like decreased $\mathrm{NO}_{3}$ content, which is harmful for tobacco quality and health of smoker. B has a positive effect on P concentration in tobacco leaves. Boron has a positive effect on potassium concentration in tobacco leaf. This positive effect of boron on potassium in tobacco is a good indicator 

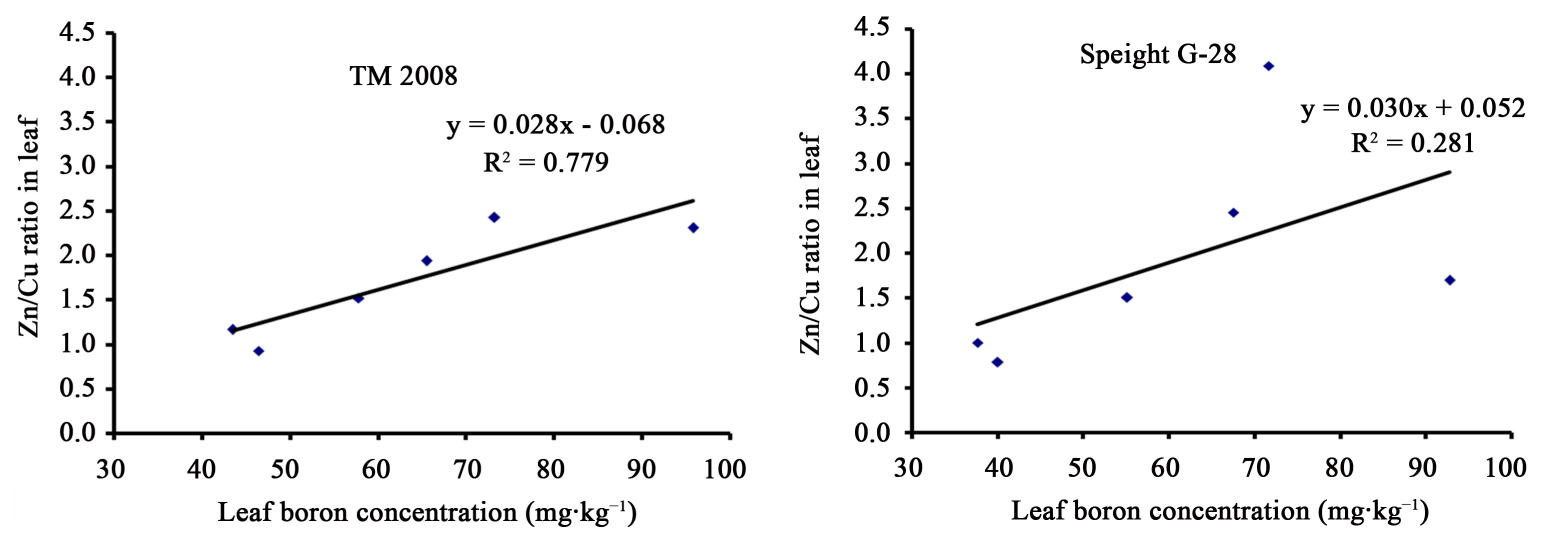

Figure 4. Relationship between boron concentration and $\mathrm{Zn} / \mathrm{Cu}$ ratio of tobacco.
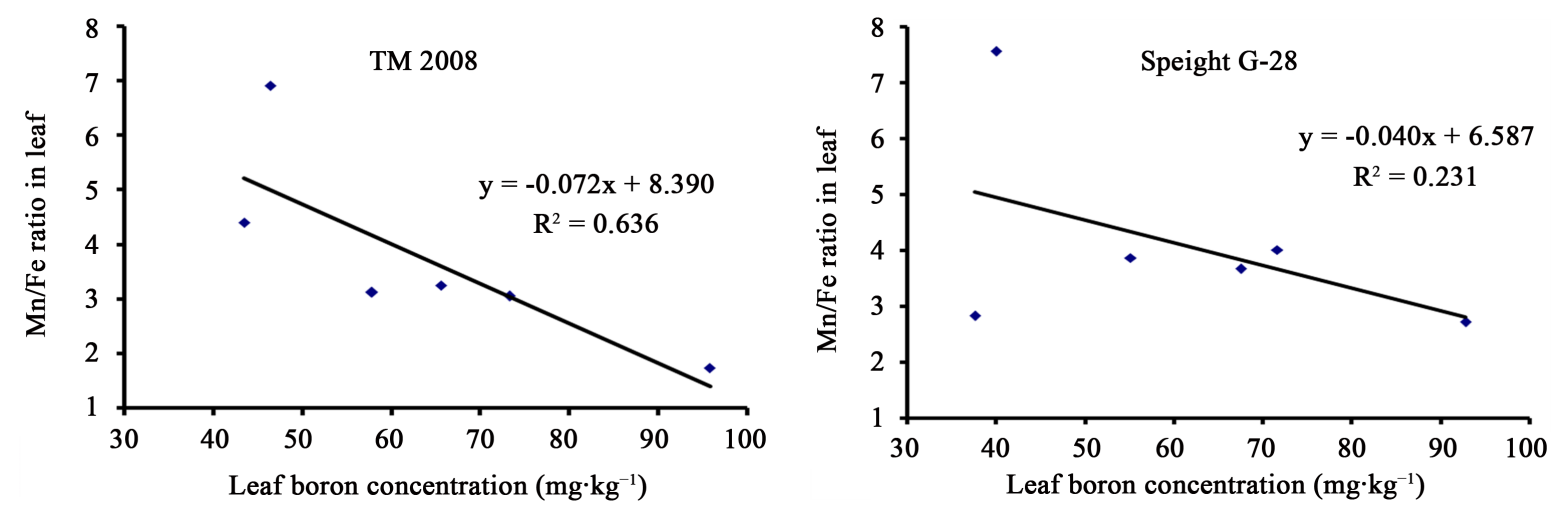

Figure 5. Relationship between boron concentration and Mn/Fe ratio of tobacco.

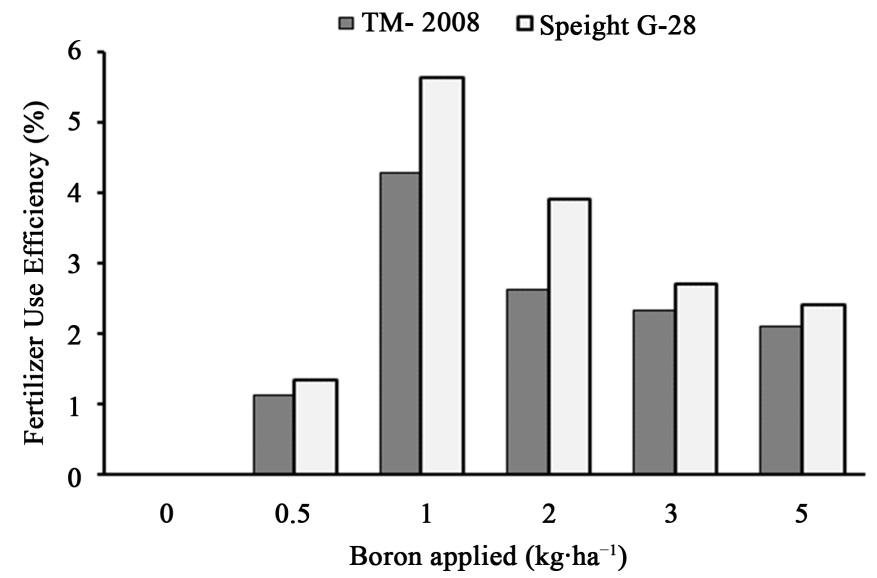

Figure 6. Effect of applied boron on the boron use efficiency in tobacco.

for good quality tobacco, because potassium enhances the smoking and ashing quality by increasing the burning quality of tobacco. Moreover, as boron concentration increases, $\mathrm{K} / \mathrm{B}, \mathrm{Cl} / \mathrm{B}$ and $\mathrm{Mn} / \mathrm{Fe}$ ratios considerably decrease. The decreasing trend in $\mathrm{Cl} / \mathrm{B}$ ratio is a good indicator for tobacco, because the $\mathrm{Cl}$ decreases the burning quality of tobacco and affects the grade index, maybe due to the competition of these two anions on the uptake sites. The $\mathrm{K} / \mathrm{Cl}$ and $\mathrm{Zn} / \mathrm{Cu}$ ratios in tobacco leaves increase with increasing concentration of boron in tobacco. Boron is responsible for the changes in $\mathrm{K} / \mathrm{Cl}$ and $\mathrm{Zn} / \mathrm{Cu}$ ratios of tobacco, and shows a close relationship of leaf boron. Although there was no significant difference between these two varieties for all the discussed parameters, Speight G-28 proved to be more efficient than TM-2008. Results clearly revealed that applied B @ 1 kg·ha ${ }^{-1}$ 
accumulated maximum boron as compared to other levels of boron fertilizers applied. Perhaps, loss of boron due to leaching, precipitation, erosion, and adsorption in soil was minimized. So it may be concluded that application of boron @ $1 \mathrm{~kg} \cdot \mathrm{ha}^{-1}$ is more effective, economical and viable than other levels of boron fertilizer applied. The fertilizer use efficiency of $1 \mathrm{~kg} \cdot \mathrm{B} \cdot \mathrm{ha}^{-1}$ proved better than other levels of applied boron and should be applied before the deficiency occurs.

\section{References}

[1] Sillanpaa, M. (1982) Micronutrients and the Nutrient Status of Soils: A Global Study. FAO Soil Bulletin No. 48, Food and Agriculture Organization, Rome.

[2] Shorrocks, V.M. (1997) The Occurrence and Correction of Boron Deficiency. Plant and Soil, 193, 121-148. http://dx.doi.org/10.1023/A:1004216126069

[3] Rashid, A. and Ryan. J. (2004) Micronutrient Constraints to Crop Production in Soils with Mediterranean Type Characteristics: A Review. Journal of Plant Nutrition, 27, 959-975. http://dx.doi.org/10.1081/PLN-120037530

[4] Rashid, A. (2006) Boron Deficiency in Soils and Crops of Pakistan: Diagnosis and Management. PARC, Islamabad, Pakistan.

[5] Imtiaz, M., Rashid, A., Khan, P., Memon, M.Y. and Aslam, M. (2010) The Role of Micronutrients in Crop Production and Human Health. Pakistan Journal of Botany, 42, 2565-2578.

[6] Marschner, H. (1995) Functions of Mineral Nutrients: Micronutrients. In: Mineral Nutrition of Higher Plants, 2nd Edition, Academic Press, London, 313-404.

[7] Koshiba, T., Kobayashi, M. and Matoh, T. (2009) Boron Nutrition of Tobacco BY-2 Cells V. Oxidative Damage Is the Major Cause of Cell Death Induced by Boron Deprivation. Plant \& Cell Physiology, 50, 26-36.

http://dx.doi.org/10.1093/pcp/pcn184

[8] Dell, B. and Huang, L. (1997) Physiological Response of Plants to Low Boron. Plant and Soil, 193, 103-120. http://dx.doi.org/10.1023/A:1004264009230

[9] Mahler, R.L. (2010) Boron in Idaho. Agricultural Experiment Station. http://www.cals.uidaho.edu/edcomm/pdf/CIS/CIS1085.pdf

[10] Belvins, D.G. and Lukaszewski, K.M. (1998) Boron in Plant Structure and Function. Annual Review of Plant Physiology and Plant Molecular Biology, 49, 481-500. http://dx.doi.org/10.1146/annurev.arplant.49.1.481

[11] Santra, G.H., Das, D.K. and Mandal, B.K. (1989) Relationship of Boron with Iron, Manganese, Copper and Zinc with Respect to Their Availability in Rice Soil. Environment and Ecology, 7, 874-877.

[12] Alvarez-Tinaut, M.C., Leal, A., Agui, I. and Recalde-Martinez, L. (1979) Physiological Effects of B-Mn Interaction in Tomato Plants. III. The Uptake and Translocation of Microelements. Analse de Edafologia y Agrobiologia, 38, 10131029.

[13] Dave, I.C. and Kannan, S. (1981) Influence of Boron Deficiency on Micronutrients Absorption by Phaseolus vulgaris and Protein Contents in Cotyledons. Acta Physiologiae Plantarum, 3, 27-32.

[14] Gomez-Rodriguez, M.V., Gomez-Ortega, M. and Alvarez-Tinaut, M.C. (1981) Boron, Copper, Iron, Manganese and Zinc Contents in Leaves of Flowering Sunflower Plants (Helianthus annuus L.) Grown with Different Boron Supplies. Plant and Soil, 62, 461-464. http://dx.doi.org/10.1007/BF02374142

[15] Tariq, M. and Mott, C.J.B. (2006) Effect of Boron Supply on the Uptake of Micronutrients by Radish (Raphanus sativus L.). Journal of Agricultural and Biological Science, 1, 1-8.

[16] Ali, F., Tariq, M., Ali, A., Shah, S.N.M., Ahmed, A. and Arifullah (2014) Effect of Different Rates of Boron on the Yield, Quality and Micronutrients Content of Tobacco (Nicotiana tabacum L.). International Journal of Farming and Allied Sciences, 3, 1165-1173.

[17] Poustini, G. and Shamel, R. (2000) Physiological and Agronomic Response of Two Burley Tobacco Cultivars to Nitrogen Fertilizer. Iranian Journal of Agricultural Sciences, 31, 363-369.

[18] Dell, P.J. (1991) The Dictionary of Modern Medicine. Penguin Books, New York.

[19] Tariq, M., Akbar, A., Lataf-ul-Haq and Khan, A. (2010) Comparing Application Methods for Boron Fertilizer on the Yield and Quality of Tobacco (Nicotiana tabacum L.). Communications in Soil Science and Plant Analysis, 41, 1525-1537. http://dx.doi.org/10.1080/00103624.2010.485234

[20] Rashid, A. (1996) Secondary and Micronutrients. In: Bashir, E. and Bantel, R., Eds., Soil Science, National Book Foundation, Islamabad, 341-386.

[21] Mozafar, A. (1989) Boron Effect on Mineral Nutrients of Maize. Agronomy Journal, 81, 285-290. http://dx.doi.org/10.2134/agronj1989.00021962008100020029x 
[22] Tariq, M., Kakar, K.M. and Shah, Z. (2005) Effect of Boron-Zinc Interaction on the Yield, Yield Attributes and Availability of Each to Wheat (Triticum aestivum L.) Grown on Calcareous Soils. Soil \& Environment, 24, 103-108.

[23] Isaac, R.A. and Kerber, J.D. (1971) Atomic Absorption and Flame Photometery: Techniques and Uses in Soil, Plant and Water Analysis. In: Walsh, L.M., Ed., Instrumental Methods for Analysis of Soil and Plant Tissue, Soil Science Society of America, Madison, USA.

[24] Bingham, F.T. (1982) Boron. In: Page, A.L., Miller, M.H. and Keeny, D.R., Eds., Methods of Soil Analysis Part-2 Chemical and Mineralogical Properties, American Society o Agronomy, Madison, 431-448.

[25] Bremner, J.M. and Mulvaney, C.S. (1982) Nitrogen-Total. In: Page, A.L., Ed., Methods of Soil Analysis. Part 2. Chemical and Microbiological Properties, American Society of Agronomy, Soil Science Society of America, Madison, 595-624.

[26] Steel, R.G.D., Torrie, J.H. and Dicke, D.A. (1997) Principles and Procedures of Statistics. A Biometrical Approach. 3rd Edition, McGraw-Hill Inc, New York.

[27] Bhatti, A.U. (1997) Irrigated Soils of NWFP. An Article Final Report of WAMA project "Waste Management in NWFP”, Department of Water Management, NWFP Agricultural University and Wageningen Agricultural University, 96-111.

[28] Soltanpour, P.N. (1985) Use of Ammonium Bicarbonate DTPA Soil Test to Evaluate Elemental Availability and Toxicity. Communications in Soil Science and Plant Analysis, 16, 323-338. http://dx.doi.org/10.1080/00103628509367607

[29] Ahmed, M., Abid, F., Ahmad, M., Aaman Ullah, M., Javaid, Q. and Ali, M.A. (2011) Impact of Boron Fertilization on Dry Matter Production and Mineral Constitution of Irrigated Cotton. Pakistan Journal of Botany, 43, 2903-2910.

[30] Ruiz, J.M., Baghour, M., Bretones, G., Belakbir, A. and Romero, L. (1998) Nitrogen Metabolism in Tobacco Plants (Nicotiana tabacum L.): Role of Boron as a Possible Regulatory Factor. International Journal of Plant Sciences, 159, 121-126. http://dx.doi.org/10.1086/297529

[31] Shafiq, M. and Maqsood, T. (2010) Response of Rice to Model Based Applied Boron Fertilizer. Journal of Agricultural Research, 48, 303-314.

[32] Hellal, F.A., Taalab, A.S. and Safaa, A.M. (2009) Influence of Nitrogen and Boron Nutrition on Nutrient Balance and Sugar Beet Yield Grown in Calcareous Soil. Ozean Journal of Applied Science, 2, 1-10.

[33] Leece, H.R. (1978) Effects of Boron on the Physiological Activity of Zinc in Maize. Australian Journal of Agricultural Research, 29, 739-749. http://dx.doi.org/10.1071/AR9780739

[34] Lopez-Lefebre, L.R., Rivero, R.M., Garcia, P.C., Sanchez, E., Ruiz, J.M. and Romero, L. (2002) Boron Effect on Mineral Nutrients of Tobacco. Journal of Plant Nutrition, 25, 509-522. http://dx.doi.org/10.1081/PLN-120003379

[35] Singh, K.P. and Sinha, H. (1976) Effect of Boron Application on K, Ca and Mg Concentrations and Their Ratios with Boron in Plants. Journal of the Institution of Chemists, 43, 189-191.

[36] Carpena-Artes, O. and Carpena-Ruiz, R.O. (1987) Effect of Boron in Tomato Plant: Leaf Evaluations. Agrochemica, 31, 391-400.

[37] Lee, S.K.D. (2000) Hot Pepper Response to Interactive Effects of Salinity and Boron. Plant Soil Environment, 52, 227-233.

[38] Ben-Gal, A. and Shani, U. (2002) Yield, Transpiration, and Growth of Tomatoes under Excess Boron and Salinity Stress. Plant and Soil, 247, 211-221. http://dx.doi.org/10.1023/A:1021556808595

[39] Hashmi, E.A., Khan, F.M., Qazi, M.Z., Woras, G. and Shah, S.A. (1990) Evaluation of Sun-Cured Varieties of Nicotiana rustica L. for Certain Agronomic and Chemical Characteristics at Mardan. Pakistan Tobacco, 1, 5-9.

[40] Alvarez-Tinaut, M.C., Leal, A. and Recalde-Martinez, L. (1980) Iron-Manganese Interaction and Its Relation to Boron Levels in Tomato Plants. Plant and Soil, 55, 377-388. http://dx.doi.org/10.1007/BF02182698

[41] Crawswell, E.T. (1987) The Efficiency of Urea Fertilizer under Different Environmental Conditions. Paper presented at the International Symposium on Urea Technology and Utilization (FADINAP), Kuala Lumpur, 16-18 March 1987.

[42] Roberts, T.L. (2008) Improving Nutrient Use Efficiency. Turkish Journal of Agriculture and Forestry, 32, $177-182$. 


\section{Abbreviation}

AB-DTPA: Ammonium Bicarbonate Diethylene Triamine Pentaacetic Acid

B: Boron

$\mathrm{CaCO}_{3}$ : Calcium Carbonate

$\mathrm{Cu}$ : Copper

$\mathrm{EC}_{\mathrm{e}}$ : Electrical Conductivity in Extract

Fe: Iron

K: Potassium

Mn: Manganese

N: Nitrogen

P: Phosphorus

Zn: Zinc 